\title{
Pesticide exposure among students and their families in Nova Friburgo, Rio de Janeiro
}

\author{
Exposição a agrotóxicos entre estudantes e seus familiares \\ em Nova Friburgo, Rio de Janeiro
}

\author{
Gesiele Veríssimo ${ }^{1}$ \\ Maria Isabel Kós ${ }^{2}$ \\ Tatiana Rodrigues Garcia ${ }^{1}$ \\ Janinne Alves dos Santos Ramos ${ }^{1}$ \\ Carolyne Cosme de Souza ${ }^{1}$ \\ Josino Costa Moreira ${ }^{3}$ \\ Armando Meyer ${ }^{1}$
}

${ }^{1}$ Instituto de Saúde Pública, Universidade Federal do Rio de Janeiro (UFRJ). Av. Horácio Macedo s/n, Fundão. 21941-598 Rio de Janeiro RJ Brasil. gesielever@gmail.com ${ }^{2}$ Faculdade de Fonoaudiologia, UFRJ. Rio de Janeiro RJ Brasil. ${ }^{3}$ Centro de Saúde do Trabalhador e Ecologia Humana, Escola Nacional de Saúde Pública Sérgio Arouca, Fiocruz. Rio de Janeiro RJ Brasil.
Abstract Farming is a risky occupation, especially family farming in developing country. The occupational hazards commonly used in such activity could affect all family members, including children and adolescents. This study describes the pattern of pesticide exposure among students and their families from a farming region located in Nova Friburgo, State of Rio de Janeiro, Brazil. Sociodemographic characteristics, habits, working practices and the degree of exposure to pesticides were assessed by a questionnaire. Our study population consisted of students and family members of both sexes, aged between 6 and 85 years old $(N$ $=352$ ) being 167 women and 185 men. There was a predominance of participants between 10-19 years $(71.3 \%)$, singles $(77.5 \%)$, and most had not completed primary education (54.5\%). In terms of occupation, $45.5 \%$ reported to be farmers and $39.6 \%$ were students. The variables mostly associated with pesticide exposure were sex $(p<0.001)$, educational level ( $p<0.001)$, and being a farmer $(p<0.001)$. Our results showed that children and teenagers seemed to have the same degree of exposure to pesticides as the adults. Our findings also suggest that sex, occupation and educational level, despite teachers were included, are directly associated with degree of exposure.

Key words Farmer, Questionnaire, Pesticide, Students
Resumo Agricultura é uma ocupação de risco, principalmente a familiar em países em desenvolvimento. Os perigos ocupacionais comuns a essa atividade podem atingir a toda família, incluindo crianças e adolescentes. Este estudo descreve o padrão do uso de agrotóxicos entre estudantes e seus familiares em uma região agrícola localizada em Nova Friburgo, Estado do Rio de Janeiro, Brasil. Características sociodemográficas, hábitos, práticas de trabalho e grau de exposição a agrotóxicos foram adquiridas através do uso de questionário. Nossa população de estudo consistiu em estudantes e seus familiares de ambos os sexos, entre 6 e 85 anos de idade $(N=352)$ sendo 167 mulheres e 185 homens. Houve a predominância de participantes entre 10 - 19 anos (71,3\%), solteiros $(77,5 \%)$, e a maioria com o ensino fundamental incompleto (54,5\%). Quanto à ocupação, 45,5\% reportaram-se como agricultores e 39,6\% como estudantes. As variáveis mais associadas à exposição a agrotóxicos foram sexo $(p<0,001)$, nível educacional $(p<0,001)$ e ser agricultor $(p<$ $0,001)$. Nossos resultados mostraram que crianças $e$ adolescentes parecem ter o mesmo grau de exposição a agrotóxicos que adultos. Nossos achados também sugerem que sexo, ocupação e nível educacional, incluindo professores, estão diretamente associados ao grau de exposição.

Palavras-chave Agricultor, Questionário, Pesticida, Estudantes 


\section{Introduction}

After World War II, the Green Revolution transformed the countryside through introduction of new technologies, such as machinery, genetic improvement, and agrochemicals ${ }^{1}$.

Among the agrochemicals the synthetic pesticides, such as DDT, were first used in large scale when little was known about the toxicological effects of these substances ${ }^{2}$. In Brazil, pesticides and chemical fertilizers gained ground in the agribusiness sector in the 1970's, upon the implementation of the National Rural Credit System (SNCR). According to this system, the amount of loans granted depended on the percentage of money to be spent on pesticides ${ }^{3}$. This resulted in significant changes which affected the environment and human health ${ }^{4,5}$.

In Brazil, pesticide sales increased by $945.51 \%$ between 1998 and 2008. While in 2010 worldwide sales of pesticides involved approximately US $\$ 48$ billion, in 2008 Brazilian pesticide market shared US\$ 7.1 billion of this amount, when the country used 986,500 tons of pesticides ${ }^{7}$. These numbers placed Brazil as the world's leader pesticide market in 2008.

The mountain region of the State of Rio de Janeiro (RJ) is one of the major producers of agricultural products in this State. According to the Brazilian Institute of Geography and Statistics $^{8}$, pesticide consumption in RJ was $18.3 \mathrm{~kg}$ per worker per year. However, in the region of Córrego de São Lourenço, a small village belonging to the city of Nova Friburgo, in the State of Rio de Janeiro, the use of pesticides was among the highest in this State, reaching $56.5 \mathrm{~kg}$ of pesticides per worker per year ${ }^{3}$. The climate, the soil and the great diversity of crops cultivated in this region, mainly in family farms, allows farming all year round, but also requires an intense use of agrochemicals especially of pesticides. In this occupational environment, where the workforce is composed basically by family members, adults and children work together and share the occupational and environmental risks imposed by this job, such as pesticide exposure ${ }^{9}$. Chemical exposure is particularly worrisome because houses and schools are commonly located very close or even inside the crop plantations, which facilitate the continuous exposure of all family members ${ }^{4}$.

Children and adolescents have unique characteristics in terms of development, which makes them more vulnerable to chemical exposure ${ }^{10,11}$.

In order to understand the pattern of pesticide exposure among students and their families in a farming region in this region of Nova Friburgo City, state of Rio de Janeiro, Brazil this work was done.

\section{Method}

The city of Nova Friburgo is located in the central region of the State of Rio de Janeiro (137 $\mathrm{km}$ from the capital). It has 182,082 inhabitants, of which $12.5 \%$ live in rural areas, where 6,792 households make their living by family farming . $^{8}$

This study was conducted in the micro region of Córrego São Lourenço, which is located 1,000$1,200 \mathrm{~m}$ above sea level, and is part of Campo do Coelho District.

Students of the agricultural school Rei Alberto I (IBELGA) and family members were invited to participate in it by signing an informed consent form. Participants younger than 18 years old had the form signed by their legal guardians. This study was approved by the Research Ethics Committee of the Institute for Studies in Collective Health, Federal University of Rio de Janeiro.

IBELGA offers technical training in farming and formal education in a very peculiar system to 300 students. To avoid evasion, students attend school in a day-long basis for one week, being taught theoretical and practical classes. After this technical training week they stay home for identical period (one week) to apply and share with their families the agricultural techniques they learned.

All students and their family were invited to take part in this study and there were no exclusion criteria. Not necessarily students included in the study had their family participating, every subject were free to choose about their inclusion or not. All participants were asked to respond questions adapted from the questionnaires used in the Agricultural Health Study ${ }^{12}$ and all answers were self-reported. Hereupon, students could also report themselves as being farmers.

Three previously trained researchers interviewed each participant. The questionnaire included demographic (address, sex, marital status, and educational level); occupation and habits (occupation, length of time working in farming, type of activities performed, type, duration, and frequency of pesticides used, and types of crops grown), and health-related questions (hypertension, high cholesterol levels, diabetes, consumption of medications).

A pesticide exposure score was calculated by assigning points to each pesticide-related and 
some occupational variables. The age of the first exposure was assigned points ranging from 0 to 2 . For the hours of work, distance between the crop fields and the participants' homes, and number of pesticides used per month, assigned points ranged from 0 to 3 , for each item. Direct contact with pesticides was assigned 0 to 4 points. The activities carried out in the field (weeding, digging holes, sowing, fertilizing, building strips of land, spreading manure, removing extra sprouts, harvesting, preparing pesticides for use, pulling a hose to spray pesticides, spraying pesticides using a backpack sprayer or a hose, washing backpack sprayer after use, and storing pesticides) were categorized following the scores proposed by Dosemeci et al. ${ }^{13}$; and ranged from 0 to 9 points (Table 1). Accordingly, pesticide exposure score varied from 0 to 76. The higher the participants' score, the higher the estimated exposure to pesticides.

We administered 356 questionnaires, and four of them were excluded from the analysis because of lacking of important answers on the forms. Our analyses were then conducted for the remaining 352 participants and do not represent the general population. The sociodemographic variables were analyzed together with the exposure variables. We used the Student's t test to compare groups regarding numeric variables with normal distribution and the Mann-Whitney test for those with asymmetric distribution. The level of significance was set at 0.05. A multiple linear regression was used to test the influence of sex, age, marital status, educational level, and occupation on the distribution of the pesticide exposure score. In line, the variables showing statistical significance in the bivariate analysis were included in the model using the stepwise technique.

\section{Results}

The sociodemographic information of the sample is shown in Table 2. We interviewed $167 \mathrm{fe}$ male (47.4\%) and 185 male participants (52.6\%). Their ages ranged from 6 to 85 years. Most of the participants were 10 to 19 years old $(72.2 \%)$, single $(77.5 \%)$, and had uncompleted primary education level $(54.5 \%)$. In terms of occupation, $162(45.5 \%)$ of the participants reported being farmers, and 141 (39.6\%) students. Moreover, $15.5 \%$ of these students reported working in the field, though they did not consider themselves as farmers. Most participants (57\%) reported actively participating in the agricultural activities
Table 1. Ranking of activities performed in the fields.

\begin{tabular}{|c|c|c|c|}
\hline $\begin{array}{l}\text { Activities performed } \\
\text { in the fields }\end{array}$ & Sometimes & Always & Never \\
\hline Weeding & 1 point & 1 point & 0 points \\
\hline Holes & 1 point & 1 point & 0 points \\
\hline Sowing & 1 point & 1 point & 0 points \\
\hline Fertilizing & 1 point & 1 point & 0 points \\
\hline Building strips of land & 1 point & 1 point & 0 points \\
\hline Spreading manure & 1 point & 1 point & 0 points \\
\hline $\begin{array}{l}\text { Removing extra } \\
\text { sprouts }\end{array}$ & 1 point & 1 point & 0 points \\
\hline Harvesting & 1 point & 1 point & 0 points \\
\hline $\begin{array}{l}\text { Preparing pesticides } \\
\text { for use }\end{array}$ & 9 points & 9 points & 0 points \\
\hline $\begin{array}{l}\text { Pulling hose to spray } \\
\text { pesticides }\end{array}$ & 8 points & 9 points & 0 points \\
\hline $\begin{array}{l}\text { Spraying pesticides } \\
\text { using backpack sprayer } \\
\text { or hose }\end{array}$ & 9 points & 9 points & 0 points \\
\hline $\begin{array}{l}\text { Washing backpack } \\
\text { sprayer after use }\end{array}$ & 8 points & 8 points & 0 points \\
\hline Storing pesticides & 9 points & 9 points & 0 points \\
\hline
\end{tabular}

Table 2. Sociodemographic data of the studied population $(\mathrm{n}=352)$.

\begin{tabular}{lrr}
\hline \multicolumn{1}{c}{ Variables } & $\mathbf{n}$ & \% \\
\hline Sex & & \\
Male & 185 & 52.6 \\
Female & 167 & 47.4 \\
Age Group & & \\
0-9 years & 6 & 1.7 \\
10-19 years & 254 & 72.2 \\
20-39 years & 53 & 15.1 \\
40-59 years & 31 & 8.8 \\
$>$ 60 years & 8 & 2.3 \\
Educational Level & & \\
Illiterate & 7 & 2 \\
Primary school & 218 & 62.6 \\
High School & 105 & 30.2 \\
Incomplete higher education & 18 & 5.1 \\
Marital Status & & \\
Single & 276 & 80.7 \\
Married & 58 & 17 \\
Other & 8 & 2.4 \\
Occupation & & \\
Farmer & 162 & 45.5 \\
Student & 141 & 39.6 \\
Other & & 14.9 \\
\hline
\end{tabular}

in the crop fields and/or in their home vegetable garden. The most common crops reported were: 
tomato $(33.33 \%)$, cauliflower (19.71\%), parsley (7.51\%), broccoli (6.57\%), and lettuce and cabbage $(6.10 \%)$.

Forty-four pesticides were mentioned as currently used. For each type of crop and/or stage of the crops, these chemicals were sprayed alone or in multiple combinations prepared by the farmers. The pesticides most frequently mentioned were: herbicides (glyphosate and paraquat), fungicide (Mancozeb), and insecticides (avermectin and methamidophos) (Table 3). The majority of the studied population $(64.6 \%)$ reported having contact with pesticides. While $22.7 \%$ of them reported direct contact while mixing and applying, $23.3 \%$ reported contact while pulling pesticide spraying hoses. In addition, $19.3 \%$ reported having indirect contact because they lived in the close vicinity of the crop fields or were responsible for washing the backpack sprayer as a daily task. Only $34.3 \%$ said they did not have contact with pesticides (Table 4 ).

The pesticide exposure score (mean: 20.83; standard deviation: 13.48) of the 352 participants ranged from 0 (the least exposed) to 76 points (the most exposed). Men had a mean score 2.2 times higher than women. The adolescents' mean was only $13 \%$ lower than the adults' value. Being a farmer raised the mean score 4.5 times compared with those who reported other professions. Table 5 shows the results of the bivariate analysis between the exposure score and sociodemographic variables. The variables showing association with pesticide exposure were $\operatorname{sex}(\mathrm{p}<0.001)$, educational level ( $\mathrm{p}<0.001)$, and occupation ( $\mathrm{p}$ $<0.001)$. Neither age group nor marital status was associated with exposure, showing a p-value of 0.381 and 0.43 , respectively. Finally the multiple linear regression reveled how predictable was the used model including sex and occupation. Being a farmer predicted $53.2 \%$ of exposure, and when the variable sex was included the exposure prediction was increased by $7.7 \%$. The linear coefficients strengthened the significance of sex and occupation on the score magnitude ( $\operatorname{sex} b=8.1$, IC 5.3 - 20.0; and occupation $b=26.1$, IC 23.2 28.9).

\section{Discussion}

Our results show that the population of this region of Nova Friburgo is frequently exposed to pesticides. Most participants reported living within 50 meters from the nearest crop field, $43.5 \%$ mentioned using pesticides at least once a month, $19 \%$ were indirectly exposed these chemicals, and $22 \%$ prepared and sprayed pesticides on their plantations. These results are similar to those found in the cohort of American farmers in the Agricultural Health Study ${ }^{14}$, which showed that $21 \%$ of the farmer's houses were located no more than 50 meters from the pesticide mixing area. In addition, $27 \%$ of families stored pesticides at home (garage or basement), and most pesticide-contaminated clothes were washed together with the family's regular clothing.

Data collected from our studied population suggest that educational level and sex are directly associated with the pesticide exposure score. The participants with the lowest educational levels had much higher exposure scores than those who had higher education degrees, which is probably due to the inclusion of teachers who were not farmers in the study. When comparing the scores of the participants who completed primary education with those who completed high school, we found similar degrees of exposure. Additionally, the older participants had a slightly higher score because they had been working in the fields for longer.

Women had statistically significant lower scores than men. Farming is heavy work, and

Table 3. Pesticides most frequently used in the rural community of Córrego de São Lourenço, Nova Friburgo, RJ, Brazil.

\begin{tabular}{|c|c|c|c|}
\hline Class of Pesticides & Name & Active Ingredient & $\%$ of use \\
\hline Insecticides / Acaricides & Tamaron ${ }^{\oplus}$ & Methamidophos & 33.4 \\
\hline Insecticides & Polytrin & Profenofos and Cypermethrin & 24.7 \\
\hline Insecticides / Nematocide & Turbo $^{\circledast}$ & Azadirachtin & 7.7 \\
\hline Insecticides & Fastac $^{\oplus}$ & Alpha-cypermethrin & 14.8 \\
\hline Insecticides / Anthelmintics & Verimec $^{\oplus}$ & Avermectin & 33.8 \\
\hline Herbicides & Roundup ${ }^{\circledast}$ & Glyphosate & 75.3 \\
\hline Herbicides & Gramoxone $e^{\oplus}$ & Paraquat & 51.7 \\
\hline Fungicides & Curzate br ${ }^{\oplus}$ & Mancozeb & 43.8 \\
\hline
\end{tabular}


Table 4. Occupational and pesticide exposure information of the students and family members at Córrego de São Lourenço, Nova Friburgo, RJ, Brazil.

\begin{tabular}{|c|c|c|c|}
\hline Variable & Score & Frequency & $\%$ \\
\hline \multicolumn{4}{|l|}{ Occupation } \\
\hline Farmer & 1 & 162 & 45.5 \\
\hline Other & 0 & 194 & 54.5 \\
\hline \multicolumn{4}{|l|}{ Hours of field work } \\
\hline 0 hour a day & 0 & 191 & 53.7 \\
\hline 1-4 hours a day & 1 & 22 & 6.2 \\
\hline 5-8 hours a day & 2 & 45 & 12.6 \\
\hline 9-10 hours a day & 3 & 88 & 24.7 \\
\hline+10 hours a day & 4 & 10 & 2.8 \\
\hline \multicolumn{4}{|l|}{ Distance between home and crops } \\
\hline More than 200 meters & 0 & 80 & 22.5 \\
\hline 100-200 meters & 1 & 34 & 9.6 \\
\hline $50-100$ meters & 2 & 61 & 17.1 \\
\hline Less than 50 meters & 3 & 181 & 50.8 \\
\hline \multicolumn{4}{|l|}{ Length of time working with pesticides } \\
\hline Has never worked with pesticides & 0 & 263 & 73.9 \\
\hline $1-5$ years & 1 & 46 & 12.9 \\
\hline $5-20$ years & 2 & 22 & 6.2 \\
\hline+20 years & 3 & 25 & 7 \\
\hline \multicolumn{4}{|l|}{ Type of contact with pesticides } \\
\hline No contact & 0 & 126 & 35.4 \\
\hline Indirect (crops near the house) & 1 & 4 & 1.1 \\
\hline Indirect (washing backpack sprayer) & 2 & 64 & 18 \\
\hline Direct (pulling hoses) & 3 & 82 & 23 \\
\hline Direct (mixing and applying pesticide on the fields) & 4 & 80 & 22.5 \\
\hline \multicolumn{4}{|l|}{ Length of time of pesticide application in the last season } \\
\hline Not one day & 0 & 215 & 60.4 \\
\hline 1-5 days & 1 & 67 & 18.8 \\
\hline 6-25 days & 2 & 53 & 14.9 \\
\hline 26-50 days & 3 & 7 & 2 \\
\hline+50 days & 4 & 14 & 3.9 \\
\hline \multicolumn{4}{|l|}{ Number of times of pesticide use per month } \\
\hline None & 0 & 201 & 56.5 \\
\hline $1-5$ times & 1 & 105 & 29.5 \\
\hline 5-10 times & 2 & 36 & 10.1 \\
\hline+10 times & 3 & 14 & 3.9 \\
\hline
\end{tabular}

men are usually responsible for direct contact with pesticides. Women are often indirectly exposed through their daily activities, such as washing clothes and equipment used in the field, as well as helping to spray the pesticides by pulling spraying hoses and cleaning pesticide-contaminated dust in their homes.

Other studies conducted in the same region showed similar results ${ }^{15}$. In the U.S. cohort, at least half of the women also reported working in the fields and $40 \%$ reported preparing and ap- plying the mix of pesticides. In addition, more than half of the U.S. children older than 11 years had farming responsibilities that exposed them to pesticides ${ }^{14}$.

This is a common reality for children from Nova Friburgo as many regularly participate in farming activities. Seventy-two percent of our study population was between 10 and 19 years old, and their mean exposure score was 20.9. Adult participants' mean score was only 3 points higher than that. This is a small difference when 
Table 5. Bivariate analysis between exposure score and sociodemographic variables.

\begin{tabular}{|c|c|c|}
\hline Variables & Mean & P-value \\
\hline Sex & & $<0.001$ \\
\hline Female & 13.0 & \\
\hline Male & 28.6 & \\
\hline Age Group & & 0.381 \\
\hline $0-9$ & 6.8 & \\
\hline $10-19$ & 20.9 & \\
\hline $20-29$ & 22.7 & \\
\hline $30-39$ & 23.6 & \\
\hline $40-59$ & 23.7 & \\
\hline 60 or older & 23.1 & \\
\hline Educational Level & & $<0.001$ \\
\hline Illiterate & 35.0 & \\
\hline Incomplete primary school & 18.7 & \\
\hline Primary school & 26.9 & \\
\hline Incomplete high school & 25.0 & \\
\hline High school & 27.3 & \\
\hline Incomplete higher education & 25.8 & \\
\hline Higher education & 2.8 & \\
\hline Marital Status & & 0.43 \\
\hline Single & 20.7 & \\
\hline Married & 26.0 & \\
\hline Widowed & 14.6 & \\
\hline Divorced & 3.8 & \\
\hline Occupation & & $<0.001$ \\
\hline Farmer & 36.4 & \\
\hline Other & 8.1 & \\
\hline
\end{tabular}

compared with the mean score of 36.5 among farmers of all ages. The findings seem to indicate that inhabit this region leads to the high exposure of this population to pesticides.

In addition to their farming tasks, children who live in rural areas have closer contact with contaminated environments because they play in fields, lakes, rivers, and plantations that have often recently been sprayed with pesticides ${ }^{16}$. Such human vulnerability needs to be considered because children's exposure is different quantitatively and qualitatively from that of adults as younger people may be more sensitive to the toxicity induced by these chemicals ${ }^{17}$. The effects of these pollutants on children's health have been receiving more attention within the scientific community because such harm to the physiological system before full development may be irreversible $^{10,11,18}$.

Studies have demonstrated associations between exposure to pesticides during childhood and cancer incidence and genetic polymorphism ${ }^{19-21}$. Higher urinary concentrations of pesticides were found in children living in rural areas when compared with children living elsewhere $^{22,23}$. A significant correlation between pesticide concentrations in children's urine and contaminated dust found in their homes has been shown by other studies ${ }^{24-26}$. This enhances the idea that the environmental exposure to pesticides in this region could potentially lead to contamination of these population.

There are many consequences to human health related to agrochemical exposure. National and international studies have correlated the use of pesticides with chronic adverse effects, such as depression and suicide ${ }^{27}$, respiratory ${ }^{28,29}$, immunological $^{30,31}$, and reproductive disorders ${ }^{32-34}$, as well as neurotoxic and teratogenic ${ }^{35-37}$, genotox$\mathrm{ic}^{38}$, and neurotoxic $\mathrm{c}^{39}$, and cancer ${ }^{40-43}$. Although there is limited information about the used types and amount types of pesticides in this studied region, the participants reported using certain high toxic pesticides already banned in most of developed countries such as paraquat and methamidophos. In 2012, one year after this study, Brazil National Health Surveillance Agency (Anvisa) prohibited methamidophos use, one example of the rural hazards that was yet used in this region by the studied period. However, others pesticides like paraquat and glyphosate are still regularly being free marketed ${ }^{44,45}$.

All inhabitants of regions where there is intensive chemical-dependent agriculture are vulnerable to the dangers inherent in this exposure. Because these chemicals are sprayed, air pollution by pesticides is one of the main reasons for the environmental exposure experienced by farming families, especially when the topography is flat or slightly sloped. When pesticides are inhaled as gases or absorbed as particles smaller than 2.5 $\mu \mathrm{m}$, pesticides are easily absorbed by the respiratory system ${ }^{46}$. Toxicity is influenced by temperature, humidity, rainfall, and winds ${ }^{47}$. In the countryside, the sunlight stimulates the volatilization process when the soil is wet, and the wind balances residue concentrations between the soil and the air ${ }^{48}$. Wind also plays an important role in dispersing these molecules ${ }^{49}$; further, while the rainfall cleans the air, the wind also contaminates the soil at different distances depending on the speed of the wind ${ }^{50}$.

Drinking water contamination is another important source of exposure for the communities that do not have water supply and sewage systems, because they use water collected from 
nearby water springs or directly from contaminated rivers or groundwater tables.

Other studies have shown that young people begin to participate in farming activities very early because of the cultural characteristics of the rural population ${ }^{51}$. In the present study, the exposure scores confirmed that simply living in a region with intense agrochemical spraying activity was enough to predispose individuals to a quite high level of exposure, even in cases of environmental exposure. Furthermore, this exposure was similar to those levels demonstrated by individuals with direct exposure in the fields. Such contamination may be caused by sleeping in a room with the windows facing a newly sprayed plantation, or walking on the roads alongside plantations, or even eating food grown using pesticides.

\section{Conclusion}

The present study has confirmed that sociodemographic characteristics, as well as habits and working practices, are related to the patterns of pesticide exposure. Our findings have revealed that children and adolescents have similar degree of exposure to pesticides as adults, suggested that sex, occupation and educational level, despite teaches were included, are directly associated with the degree of exposure to this substances. These results enhance a warning sign about the risks of pesticide exposure during early phases of the development.

\section{Collaborations}

G Veríssimo, MI Kós, TR Garcia, JAS Ramos, CC Souza, JC Moreira and A Meyer participated equally in all stages of preparation of the article. 


\section{References}

1. Andrades TO, Ganimi RN. Revolução verde e a apropriação capitalista. CES Revista 2007; 21:43-56.

2. Organização Pan-Americana de Saúde (OPAS). Manual de Vigilância da Saúde de populações expostas a agrotóxicos. Brasília: OPAS; 1997.

3. Peres F. É veneno ou é remédio? Os desafios da comunicação rural sobre agrotóxicos. Rio de Janeiro: Fiocruz; 1999.

4. Moreira JC, Jacob SC, Peres F, Lima JS, Meyer A, Oliveira-Silva JJ, Sarcinelli PN, Batista DF, Egler M, Faria MVA, Araújo AJ, Kubota AH, Soares MO, Alves SR, Moura CM, Curi R. Avaliação integrada do impacto do uso de agrotóxicos sobre a saúde humana em uma comunidade agrícola de Nova Friburgo, RJ. Cien Saude Colet 2002; 7(2):299-311.

5. Alves SR. Avaliação dos resíduos de agrotóxicos organofosforados e carbamatos por metodologia enzimática no Córrego de São Lourenço, Nova Friburgo-RJ, Brasil. Rio de Janeiro: Fiocruz; 2000.

6. Sindicato Nacional das Empresas de Aviação Agrícola (SINDAG). Vendas de agrotóxicos por estados brasileiros 2012 [cited 2012 Oct 1]; Available from: http://www. sindag.com.br/EST97989900.zip.

7. Agência Nacional de Vigilância Sanitária (Anvisa). Seminário volta a discutir mercado de agrotóxicos em 2012. Sala de Imprensa 2012 [cited 2013 Jul 1]; Available from: http://portal.anvisa.gov.br/wps/content/ anvisa+portal/anvisa/sala+de+imprensa/menu+-+noticias+anos/2012+noticias/seminario+volta $+a+$ discutir+mercado+de+agrotoxicos+em+2012.

8. Instituto Brasileiro de Geografia e Estatística (IBGE). Censo Demográfico. 2010. [cited 2013 Jun 1]. Available from: http://www.ibge.gov.br/cidadesat/xtras/perfil. php? codmun $=330340$

9. Peres F, Rozemberg B. Pesticide use reporting in a rural area of Rio de Janeiro state, Brazil. Rev Saude Publica 2001; 35(6):564-570.

10. Kreipe RE, McAnarney ER. Adolescent Medicine. In: Behrman RE, Kliegman RB, editors. Essentials of Pediatrics. $2^{\text {nd }}$ ed. Philadelphia: W.B. Saunders \& Co; 1994. p. 215-229.

11. Sanborn M, Cole D, Kerr K, Vakil C, Sanin LH, Bassil K. Pesticides Literature Review: Systematic Review of Pesticide Human Health Effects. Ontario: The Ontario College of Family Physicians; 2012.

12. Agricultural Health Study (AHS). Farmer Applicator Questionnaire. 1996. [cited 2011 Jun 1]; Available from: http://aghealth.nih.gov/collaboration/questionnaires. html.

13. Dosemeci M, Alavanja MC, Rowland AS, Mage D, Zahm SH, Rothman N, Lubin JH, Hoppin JA, Sandler DP, Blair A. A quantitative approach for estimating exposure to pesticides in the Agricultural Health Study. Ann Occup Hyg 2002; 46(2):245-260.

14. Gladen BC, Sandler DP, Zahm SH, Kamel F, Rowland AS, Alavanja MC. Exposure opportunities of families of farmer pesticide applicators. Am J Ind Med 1998; 34(6):581-587.
15. Araujo AJ, Lima JS, Moreira JC, Jacob SC, Soares MO, Monteiro MC, Amaral AM, Kubota A, Meyer A, Cosenza CA, Neves C, Markowitz S. [Multiple exposure to pesticides and impacts on health: a cross-section study of 102 rural workers, Nova Friburgo, Rio de Janeiro State, Brazil]. Cien Saude Colet 2007; 12(1):115-130.

16. Mazoto ML, Filhote MIF, Câmara VM, Asmus CIRF. Environmental childhood health: proposals and perspectives review. Cad. Saúde Colet. 2011; 19(1):41-50.

17. Sarcinelli PN. A exposição de crianças e adolescentes a agrotóxicos. In: Peres F, Moreira JC, organizadores. $E$ veneno ou é remédio?: agrotóxicos, saúde e ambiente. Rio de Janeiro: Editora Fiocruz; 2003. p. 43-58.

18. Gamlin J, Hesketh T. Child work in agriculture: acute and chronic Health Hazards. AAOHN J 2007; 17(4):123.

19. Infante-Rivard C, Labuda D, Krajinovic M, Sinnett D. Risk of childhood leukemia associated with exposure to pesticides and with gene polymorphisms. Epidemiology 1999; 10(5):481-487.

20. Meinert R, Schüz J, Kaletsch U, Kaatsch P, Michaelis J. Leukemia and non-Hodgkin's lymphoma in childhood and exposure to pesticides: results of a register-based case-control study in Germany. Am J Epidemiol 2000; 151(7):639-646; discussion 647-650.

21. Reynolds P. Agricultural exposures and childhood cancers. Rev Environ Health 2009; 24(4):339-344.

22. Panuwet P, Prapamontol T, Chantara S, Barr DB. Urinary pesticide metabolites in school students from northern Thailand. Int J Hyg Environ Health 2009; 212(3):288-297.

23. Panuwet P, Prapamontol T, Chantara S, Thavornyuthikarn P, Bravo R, Restrepo P, Walker RD, Williams BL, Needham LL, Barr DB. Urinary paranitrophenol, a metabolite of methyl parathion, in Thai farmer and child populations. Arch Environ Contam Toxicol 2009; 57(3):623-629.

24. Becker K, Seiwert M, Angerer J, Kolossa-Gehring M, Hoppe HW, Ball M, Schulz C, Thumulla J, Seifert B. GerES IV pilot study: assessment of the exposure of German children to organophosphorus and pyrethroid pesticides. Int J Hyg Environ Health 2006; 209(3):221233.

25. Bouchard MF, Bellinger DC, Wright RO, Weisskopf MG. Attention-deficit/hyperactivity disorder and urinary metabolites of organophosphate pesticides. Pediatrics 2010; 125(6):e1270-1277.

26. Barr DB, Olsson AO, Wong LY, Udunka S, Baker SE, Whitehead RD, Magsumbol MS, Williams BL, Needham LL. Urinary concentrations of metabolites of pyrethroid insecticides in the general U.S. population: National Health and Nutrition Examination Survey 19992002. Environ Health Perspect 2010; 118(6):742-748.

27. Chrisman JR, Koifman S, de Novaes Sarcinelli P, Moreira JC, Koifman RJ, Meyer A. Pesticide sales and adult male cancer mortality in Brazil. International journal of hygiene and environmental health 2009; 212(3):310321. 
28. Castro-Gutierrez N, McConnell R, Andersson K, Pacheco-Antón F, Hogstedt C. Respiratory symptoms, spirometry and chronic occupational paraquat exposure. Scand J Work Environ Health 1997; 23(6):421-427.

29. Valcin M, Henneberger PK, Kullman GJ, Umbach DM, London SJ, Alavanja MC, Sandler DP, Hoppin JA. Chronic bronchitis among nonsmoking farm women in the agricultural health study. J Occup Environ Med 2007; 49(5):574-583.

30. Chatzi L, Alegakis A, Tzanakis N, Siafakas N, Kogevinas $\mathrm{M}$, Lionis C. Association of allergic rhinitis with pesticide use among grape farmers in Crete, Greece. Occup Environ Med 2007; 64(6):417-421.

31. Okabe M, Nishimoto S, Sugahara T, Akiyama K, Kakinuma Y. Oral administration of paraquat perturbs immunoglobulin productivity in mouse. $J$ Toxicol Sci 2010; 35(2):257-263.

32. Meyer A, Sarcinelli PN, Moreira JC. [Are some Brazilian population groups subject to endocrine disrupters?]. Cad Saude Publica 1999; 15(4):845-850.

33. Koifman S, Koifman RJ, Meyer A. Human reproductive system disturbances and pesticide exposure in Brazil. Cad Saude Publica 2002; 18(2):435-445.

34. Gibson G, Koifman S. Agricultural toxic use and temporal distribution of male birth rate in the state of $\mathrm{Pa}$ rana, Brazil. Rev Panam Salud Publica 2008; 24(4):240247.

35. Hertzman C, Wiens M, Bowering D, Snow B, Calne D. Parkinson's disease: a case-control study of occupational and environmental risk factors. Am J Ind Med 1990; 17(3):349-355.

36. Liou HH, Tsai MC, Chen CJ, Jeng JS, Chang YC, Chen SY, Chen RC. Environmental risk factors and Parkinson's disease: a case-control study in Taiwan. Neurology 1997; 48(6):1583-1588.

37. Landrigan PJ, Sonawane B, Butler RN, Trasande L, Callan R, Droller D. Early environmental origins of neurodegenerative disease in later life. Environ Health Perspect 2005. 113(9):1230-1233.

38. Bolognesi C. Genotoxicity of pesticides: a review of human biomonitoring studies. Mutation research 2003; 543(3):251-272.

39. Tanner CM, Ross GW, Jewell SA, Hauser RA, Jankovic J, Factor SA, Bressman S, Deligtisch A, Marras C, Lyons KE, Bhudhikanok GS, Roucoux DF, Meng C, Abbott $\mathrm{RD}$, Langston JW. Occupation and risk of parkinsonism: a multicenter case-control study. Arch Neurol 2009; 66(9):1106-1113.

40. Meyer A, Chrisman J, Moreira JC, Koifman S. Cancer mortality among agricultural workers from Serrana Region, state of Rio de Janeiro, Brazil. Environ Res 2003; 93(3):264-271.

41. Koifman S, Koifman RJ. Environment and cancer in Brazil: an overview from a public health perspective. Mutation research 2003; 544(2-3):305-311.

42. Turner MC, Wigle DT, Krewski D. Residential pesticides and childhood leukemia: a systematic review and meta-analysis. Environ Health Perspect 2010; 118(1):33-41.
43. Alavanja MC, Sandler DP, Lynch CF, Knott C, Lubin JH, Tarone R, Thomas K, Dosemeci M, Barker J, Hoppin JA, Blair A. Cancer incidence in the agricultural health study. Scand J Work Environ Health 2005; 31(Supl. 1):39-45; discussion 5-7.

44. Jardim ANO, Caldas ED. Brazilian monitoring programs for pesticide residues in food - Results from 2001 to 2010. Food Control 2012; 25(2):607-616.

45. Brasil. Anvisa (Brazilian Sanitary Surveillance Agency). Resolução-RDC no 1, de 14 de janeiro de 2011. Regulamento técnico para o ingrediente ativo Metamidofós em decorrência da reavaliação toxicológica. Diário Oficial da União 2011; 17 jan.

46. Noyes PD, McElwee MK, Miller HD, Clark BW, Van Tiem LA, Walcott KC, Erwin KN, Levin ED. The toxicology of climate change: environmental contaminants in a warming world. Environ Int 2009; 35(6):971-986.

47. Bloomfield JP, Williams RJ, Gooddy DC, Cape JN, Guha P. Impacts of climate change on the fate and behaviour of pesticides in surface and groundwater--A UK perspective. Sci Total Environ 2006; 369(1-3):163177.

48. van den Berg E, Oliveira-Filho AT. Spatial partitioning among tree species within an area of tropical montane gallery forest in south-eastern Brazil. Flora 1999; 194(3):249-266

49. Siebers J, Binner R, Wittich KP. Investigation on downwind short-range transport of pesticides after application in agricultural crops. Chemosphere 2003; 51(5):397-407.

50. Beyer A, Wania F, Gouin T, Mackay D, Matthies M. Temperature dependence of the characteristic travel distance. Environ Sci Technol 2003; 37(4):766-771.

51. White B. Agriculture and the Generation Problem: Rural Youth, Employment and the Future of Farming. Ids Bulletin-Institute of Development Studies 2012; 43(6):919.

Artigo apresentado em 27/06/2016

Aprovado em 25/11/2016

Versão final apresentada em 27/11/2016 
